Gut, 1982, 23, 357-361

\title{
Pancreatic exocrine function in severe human chronic renal failure*
}

\author{
C OWYANG, $\dagger$ L J MILlER, E P DiMAGNO, $\ddagger$ J C MITCHELL III, and V L W GO \\ From the Gastroenterology Unit, Mayo Clinic and Mayo Foundation, Rochester, MN, USA
}

SUMMARY Patients with chronic renal failure have an abnormal immunoreactive gastrointestinal hormone profile, which is characterised by raised fasting serum concentrations of hormones that have antagonistic effects on exocrine pancreatic function. In addition, in this present study we have found that in renal insufficiency cholecystokinin disappears slowly from the plasma after a constant intravenous infusion of the hormone $(p=0.05$ compared with healthy subjects). To evaluate whether the stimulatory or inhibitory hormones have a predominant effect, pancreatic exocrine function under conditions of mannitol perfusion of the duodenum and continuous intravenous cholecystokinin stimulation was studied in eight patients who had severe chronic renal failure and eight age-matched and sex-matched control subjects. Compared with healthy subjects, patients with renal insufficiency had hypersecretion of trypsin in response both to mannitol perfusion of the duodenum and to cholecystokinin stimulation $(p<0.05)$. No significant differences in lipase secretion were noted between the patients with renal insufficiency and control subjects. These findings are consistent with the hypothesis that, of the abnormally raised fasting serum concentrations of gastrointestinal hormones found in renal insufficiency, hormones that stimulate rather than inhibit pancreatic exocrine function predominate. Secondly, the dissociation between trypsin and lipase outputs in chronic renal failure may suggest a differential trophic influence of stimulatory hormones - that is, hypercholecystokininaemia - on pancreatic exocrine enzyme secretion.

Patients with chronic renal failure have an abnormal gastrointestinal hormone profile, which is characterised by raised serum concentrations of cholecystokinin $(\mathrm{CCK}),{ }^{1}$ a powerful stimulator of pancreatic exocrine function, as well as inhibitors of pancreatic secretion such as glucagon ${ }^{12}$ and pancreatic polypeptide. $^{3}$ The effect of this abnormal hormone profile $^{1}$ on pancreatic function, however, is not known. Also, several of these hormones may have trophic effects on the pancreas. ${ }^{4}$

To evaluate whether the stimulators or inhibitors of pancreatic secretion have a predominant effect and whether a trophic effect of these hormones can be shown, we studied pancreatic enzyme secretion in response to mannitol perfusion of the duodenum (control) and maximal pancreatic enzyme secretory

\footnotetext{
* This investigation was supported in part by Research Grant AM 7198 from the National Institutes of Health, Public Health Service, Bethesda, MD, USA. † Present address: GI Research Unit, University Hospital, Ann Arbor, MI 48104, USA.

$\ddagger$ Address for reprint requests: E P DiMagno, MD, Gastroenterology Unit, Mayo Clinic, Rochester, MN 55905, USA.

Received for publication 4 September 1981
}

capacity (CCK-stimulated) in a group of patients with severe chronic renal failure and in age-matched and sex-matched normal subjects and then measured the disappearance of CCK after terminating a continuous CCK intravenous infusion.

\section{Methods}

SUBJECTS

Eight patients (men, aged 25 to 62 years) with severe chronic renal failure (serum creatinine concentrations 12.0 to $16.9 \mathrm{mg} / \mathrm{dl}$, mean 14.3 ) and eight age-matched and sex-matched controls were studied after giving written informed consent. The patients with renal failure were on chronic haemodialysis programmes for at least 18 months before the study and had their care in medicinal programme supervised by one of us (JCM). The patients were studied on non-dialysis days, when serum ionised calcium concentrations were normal and non-fluctuating. All patients were dialysed against a $0.75-0.88 \mathrm{mmol} / 1$ (3.0-3.5 mEq/l) calcium bath, which usually causes a transient (three to 12 hours) increase of serum 
calcium concentrations of no more than $0.5-0.75$ $\mathrm{mmol} / \mathrm{l}(1-1.5 \mathrm{mg} / 100 \mathrm{ml})$. All subjects were within $10 \%$ of their ideal weight, instructed to eat a normal protein diet, and had no previous gastrointestinal or biliary surgery or other significant co-existent endocrinopathy. All patients had normal serum concentrations of glucose and calcium and were taking no medication known to interfere with pancreatic function.

\section{PROCEDURE}

Pancreatic lipase and trypsin secretions were studied using our standard gastroduodenal intubation perfusion technique. ${ }^{5}$ To summarise this technique, after an overnight fast a double-lumen duodenal tube and a separate gastric sump tube were positioned fluoroscopically so that the duodenal perfusion site was in the second part of the duodenum, the duodenal aspiration site was $20 \mathrm{~cm}$ distal to this at the ligament of Treitz, and the gastric sump tube was in the gastric antrum. The duodenal perfusion solution used was an isotonic solution of mannitol containing a non-absorbable marker polyethylene glycol (PEG 4000) $(5 \mathrm{~g} / \mathrm{l})$ warmed to $37^{\circ} \mathrm{C}$ and adjusted to $\mathrm{pH} 7 \cdot 0$. Mannitol was used in this series of studies instead of our usual saline perfusate because of the necessity to restrict sodium in renal failure. Duodenal samples were collected at the level of the ligament of Treitz by siphonage and were pooled every 20 minutes over ice. Gastric contents were aspirated from the antrum by continuous mechanical suction. After steady-state conditions were established, samples were collected for two hours. Then collections were continued for one hour while pancreatic enzyme secretion was stimulated by the continuous intravenous infusion of $20 \%$ porcine CCK (GIH Laboratory, Karolinska Institute, Stockholm) given at a rate of $0.25 \mathrm{CHR}$ $\mathrm{U} / \mathrm{kg} / \mathrm{min}$.

Four normal subjects and five of the patients with renal insufficiency donated blood at two, four, seven, nine, 12,15 , and 20 minutes after the end of the one-hour continuous intravenous infusion of $20 \%$ porcine CCK. Of the $7 \mathrm{ml}$ of peripheral venous blood collected, $3 \mathrm{ml}$ was collected in aprotinin (Trasylol)-ethylenediaminetetra-acetate tubes, and $4 \mathrm{ml}$ was allowed to clot. These samples were centrifuged at $44^{\circ} \mathrm{C}$, and plasma and serum were divided into aliquots and frozen at $-20^{\circ} \mathrm{C}$ until assays could be performed.

Cholecystokinin was measured by a radioimmunoassay recently developed in our laboratory. ${ }^{6}$ Radioiodination of $99 \%$ pure porcine CCK (kindly supplied by Dr V Mutt, Karolinska Institute, Stockholm, Sweden) was accomplished by having the hormone react with succinimide ester of ${ }^{125} \mathrm{I}$ - labelled 3-(4-hydroxyphenyl) propionic acid according to the new Bolton-Hunter method. ${ }^{7}$ The specific activity was $50 \mu \mathrm{Ci} / \mu \mathrm{g}$. Antiserum (No 3482) used in the assay was raised in New Zealand rabbits by repeated intradermal injections of $20 \%$ pure porcine CCK. It was used at a final dilution of 1:25000. This antiserum had no significant cross-reactivity with human heptadecapeptide gastrin (G-17). The assay detected serum CCK at a concentration of 50 $\mathrm{pg} / \mathrm{ml}$. The intra-assay and interassay coefficient of variation for duplicate systems was less than $13 \%$. Results of the serum CCK were expressed in picograms per millilitre, with CCK-33 used as the standard.

Concentrations of polyethylene glycol, ${ }^{8}$ trypsin, ${ }^{9}$ and lipase ${ }^{9}$ were measured in all duodenal samples. Trypsin and lipase concentrations were determined by means of an automatic titration method using TAME ( $p$-toluene sulfonyl-2-arginine methyl ester) and fat emulsion (Lipomul) as substrates for the respective enzyme activities. ${ }^{9}$ The enzyme outputs were calculated, based on recovery of polyethylene glycol $^{5}$ and expressed in $10^{3} \mathrm{U} /(\mathrm{kU})$ per hour.

Differences between enzyme secretion during mannitol perfusion of the duodenum and CCKstimulated pancreatic enzyme secretion obtained from patients with chronic renal failure and those obtained from the normal controls were tested using Student's $t$ test, with $\mathrm{p}<0.05$ being significant.

\section{Results}

\section{TRYPSIN SECRETION}

In response to duodenal mannitol perfusion the mean pancreatic trypsin output in chronic renal failure of $51 \pm 10 \mathrm{kU} / \mathrm{h}$ (mean $\pm \mathrm{SD}$ ) was significantly higher than the mean trypsin output of $23 \pm 8$ observed in healthy controls $(p<0 \cdot 01)$ (Fig. 1). There was no overlap in trypsin outputs between these groups.

Despite the patient's raised trypsin outputs in response to duodenal mannitol perfusion and their raised fasting serum $\mathrm{CCK}$ concentrations, ${ }^{1}$ the intravenous infusion of exogenous porcine CCK further increased the trypsin output in every patient with chronic renal failure $(\mathrm{p}<0 \cdot 01)$ (Fig. 1). Trypsin output increased fourfold after intravenous CCK stimulation $(51 \pm 10 \mathrm{kU} / \mathrm{h}$ to $213 \pm 108)$. In the control group the trypsin output increased from $23 \pm 8 \mathrm{kU} / \mathrm{h}$ to $37 \pm 11$ with intravenous CCK stimulation (Fig. 1). Thus the pancreatic trypsin secretion, determined in response to the maximal CCK stimulus, was greater in patients with chronic renal failure than in healthy controls $(p<0.01)$. Furthermore, the increase in trypsin secretion, expressed as a percentage of secretion in response to mannitol 


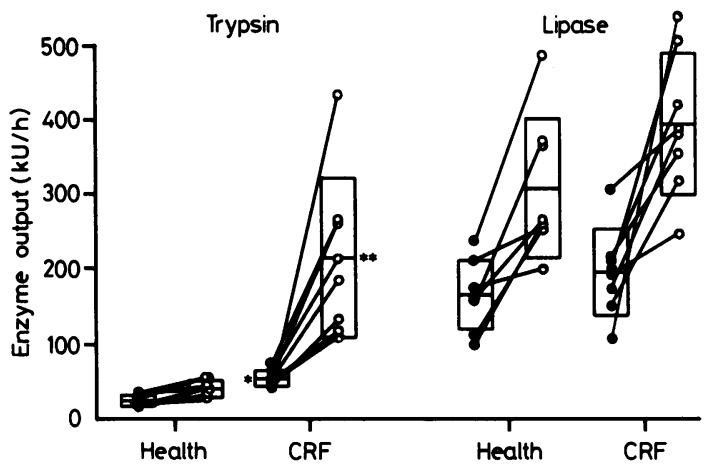

Fig. 1 Pancreatic trypsin and lipase outputs in response to intraduodenal (ID) mannitol perfusion ( $\bullet$ ) and intravenous cholecystokinin $(C C K)(O)$ in health and severe chronic renal failure (CRF). Vertical columns represent mean \pm 1 standard deviation; * $p<0.01$ (chronic renal failure ID mannitol compared with health ID mannitol); ${ }^{* *} p<0.01$ (chronic renal failure CCK compared with health CCK); $k U$ represents $10^{3}$ units.

perfusion, was greater in chronic renal failure than in health $(431 \pm 263 \% v 172 \pm 43 \%, \mathrm{p}<0.01)$ (Fig. 2).

\section{LIPASE SECRETION}

In contrast with the higher than normal trypsin output observed in chronic renal failure there was no significant difference in lipase output in response to mannitol perfusion between patients with chronic renal failure and healthy controls $(194 \pm 58 v 163 \pm 46$ $\mathrm{kU} / \mathrm{h}, \mathrm{p}>0.05$ ) (Fig. 1). The intravenous infusion of porcine CCK resulted in a similar significant increase in lipase output in every patient with chronic renal failure $(194 \pm 58$ to $393 \pm 95 \mathrm{kU} / \mathrm{h}$, $\mathrm{p}<0.05)$ and in health $(163 \pm 46$ to $307 \pm 94 \mathrm{kU} / \mathrm{h}$, $\mathrm{p}<0.05)$. Lipase output with CCK administration in

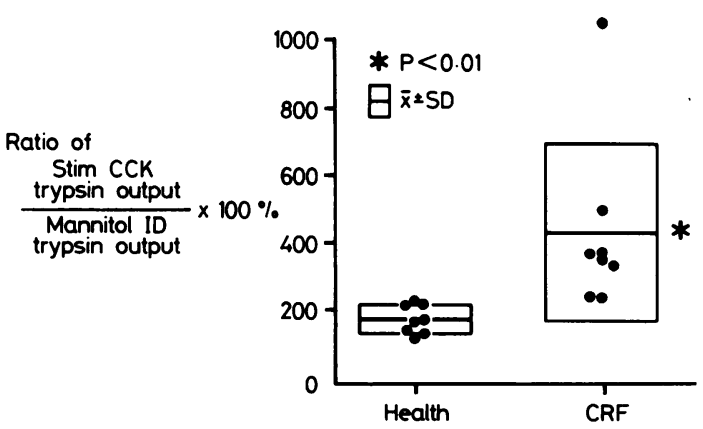

Fig. 2 Maximal stimulated pancreatic trypsin secretion in response to CCK expressed as a percentage of that elicited by duodenal mannitol perfusion is shown for healthy controls and patients with severe chronic renal failure $(C R F)$. Individual data and group means $\pm S D$ are shown; ${ }^{*} p<0.01$. chronic renal failure was not significantly different from that observed in healthy controls.

IMMUNOREACTIVE CCK DISAPPEARANCE STUDY After the end of the continuous intravenous infusion of $20 \%$ porcine CCK, the disappearance of CCK from the blood during the first seven minutes (Table, Fig. 3) appeared to be the same for normal subjects and patients with chronic renal failure. After the initial seven minutes, however, CCK disappearance in the patients with renal failure was significantly slower $(p=0 \cdot 05$; Table $)$.

\section{Discussion}

We have previously shown that the fasting gastrointestinal immunoreactive hormones are significantly higher in renal insufficiency compared with normal subjects and suggested that they could alter gastrointestinal functions in these patients. ${ }^{1} \mathrm{We}$ have now shown that patients with renal failure have hypersecretion of pancreatic trypsin but not lipase in response to a mannitol duodenal perfusion and to intravenous infusion of CCK. These findings might be explained by the augmentation of the raised fasting serum concentrations of gastrointestinal hormones in which stimulatory hormones such as CCK rather than inhibitory hormones have the predominant effect. ${ }^{10-16}$ Indeed, we have found that in patients with renal insufficiency the plasma disappearance of CCK is slow, and normal fasting levels are not achieved. These data emphasise that in renal insufficiency there is continuous CCK stimulation of the exocrine pancreas, which may cause pancreatic hypertrophy, hyperplasia, or increased sensitivity of the acinar cells to stimulating hormones such as CCK or gastrin or both.

In the rat $^{4} 1718$ chronic injection of CCK increases pancreatic weight and pancreatic content of protein, DNA, RNA amylase, and trypsin. Furthermore, Barrowman and Mayston ${ }^{17}$ reported that the chronic injection of $\mathrm{CCK}$ in rats resulted in a striking increase of pancreatic content of amylase

Table Disappearance of blood during first seven minutes

\begin{tabular}{lll}
\hline Slope (min) & $\begin{array}{l}\text { Normal subjects } \\
(n=4)\end{array}$ & $\begin{array}{l}\text { Patients with } \\
\text { renal insufficiency } \\
(n=5)\end{array}$ \\
\hline 0 to 7 & $-4400 \pm 1655$ & $\begin{array}{l}-3627 \pm 1580 \\
9 \text { to } 20\end{array}$ \\
\hline
\end{tabular}

Mean and standard error of the first seven and last 12 minutes of the CCK disappearance curves for normal subjects and patients with renal insufficiency. Slopes calculated by linear regression. * $p=0.05$ compared with 9-20 minute mean value in the normal subjects. 


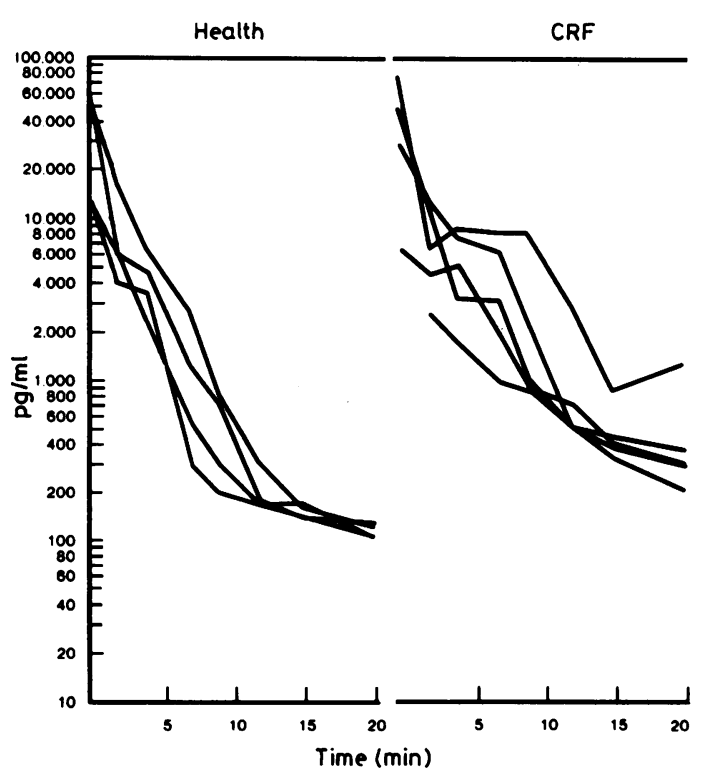

Fig. 3 Plasma CCK disappearance curves after end of a constant intravenous infusion of cholecystokinin for four normal control subjects (health) and five patients with severe chronic renal failure (CRF).

and proteolytic enzymes but not of lipase. Our data, which show a dissociation between trypsin and lipase outputs in patients with chronic renal failure in whom we have shown hypercholecystokininaemia, are consistent with this differential trophic influence on pancreatic exocrine enzymes.

Theoretically, the differences between trypsin and lipase secretion could be due to adaptation of pancreatic enzymes to dietary composition. ${ }^{19}$ Recently, Felber and his colleagues ${ }^{20}$ reported that carbohydrates, lipids, and proteins induced the preferential secretion of amylase, lipase, or trypsin and chymotrypsin, respectively. Our patients, however, were receiving a normal protein diet. Therefore, it is unlikely that dietary manipulation had a major role in influencing pancreatic enzyme secretion in our patients.

In our healthy subjects trypsin output in response to duodenal mannitol perfusion was three to four times the amount secreted in response to duodenal saline perfusion ${ }^{10}{ }^{11}$ but is submaximal and the same as that observed with duodenal perfusion of an essential amino-acid mixture. ${ }^{10} 12$ Thus mannitol perfusion of the intestine probably activates a neurohormonal mechanism that stimulates pancreatic secretion, which is augmented in renal failure. Similarly, intravenous infusion of porcine CCK at a dose of $0.25 \mathrm{CHR} \mathrm{U} / \mathrm{kg} / \mathrm{min}$ produces maximal secretion of pancreatic enzymes in healthy subjects. ${ }^{11} 12$ In chronic renal failure, however, the pancreatic trypsin secretion in response to this CCK stimulus was significantly greater than in healthy controls.

In all other studies normal or decreased pancreatic secretion has been found in chronic renal insufficiency. Normal ${ }^{21}$ or decreased ${ }^{22}{ }^{23}$ bicarbonate secretion in response to secretin and normal ${ }^{24}$ or decreased 212325 CCK-stimulated amylase output have been reported. When trypsin ${ }^{21} 23$ or lipase 21 outputs have been measured they have usually been normal. Lipase outputs, however, were found to be abnormally low in 15 of 25 patients. ${ }^{25}$ That our results differ from these studies may be due to different techniques (we measured outputs by recovery of an unabsorbable marker), awareness of the possibility of increased secretion, and selection of patients.

The clinical importance of hypersecretion of pancreatic trypsin in chronic renal failure is uncertain at present. None of the eight subjects whom we studied had experienced a typical episode of pancreatitis. A high prevalence of pancreatic disease in chronic renal failure, however, has been reported, ${ }^{26} 27$ and in one necropsy report ${ }^{27}$ pathological changes in the pancreas were present in $56.8 \%$ of the cases in which maintenance haemodialysis had been used before death from uraemia. Histological changes included duct ectasia, periductal fibrosis, ductular proliferation, acinar ductular metaplasia, and interstitial fibrosis. ${ }^{27}$ It is tempting to speculate that pancreatic trypsin hypersecretion may initiate pancreatic disease in this group of patients. The significance of this finding, however, still awaits further clinical and pathological studies.

\section{References}

1 Owyang C, Miller LJ, Go VLW, DiMagno EP, Brennan LA, Jr. The gastrointestinal hormone profile in renal insufficiency. Mayo Clin Proc 1979; 54: 769-73.

2 Bilbrey GL, Faloona GR, White MG, Knochel JP, Borroto J. Hyperglucagonemia of renal failure. J Clin Invest 1974; 53: 841-7.

3 Hallgren R, Lundqvist G, Chance RE. Serum levels of human pancreatic polypeptide in renal disease. Scand $J$ Gastroenterol 1977; 12: 923-7.

4 Enochs MR, Johnson LR. Hormonal regulation of gastrointestinal tract growth: biochemical and physiological aspects. In: Jerzy Glass GB, ed. Progress in gastroenterology. New York: Grune and Stratton, 1977: 3-28.

5 Go VLW, Hofmann AF, Summerskill WH. Simultaneous measurements of total pancreatic, biliary, and gastric outputs in man using a perfusion technique. Gastroenterology 1970: 58: 321-8. 
6 Go VLW, Owyang C. Radioimmunoassay of gastrointestinal hormones. In: Jerzy Glass GB, ed. Progress in gastroenterology. New York: Grune and Stratton, 1977: 153-78.

7 Bolton AE, Hunter WM. The labelling of proteins to high specific radioactivities by conjugation to a ${ }^{125} \mathrm{I}$ containing acylating agent: application to the radioimmunoassay. Biochem J 1973; 133: 529-39.

8 Hyden S. A turbidimetric method for the determination of higher polyethylene glycols in biological materials. K Lantbrukshogsk Ann 1956; 22: 139-45.

9 Pelot D, Grossman MI. Distribution and fate of pancreatic enzymes in small intestine of the rat. $A m J$ Physiol 1962; 202: 285-8.

10 DiMagno EP, Go VLW, Summerskill WH. Intraluminal and post-absorptive effects of amino acids on pancreatic enzime secretion. J Lab Clin Med 1973; 82: 241-8.

11 DiMagno EP, Malagelada J-R, Go VLW. Relationship between alcoholism and pancreatic insufficiency. Ann NY Acad Sci 1975; 252: 200-7.

12 DiMagno EP, Go VLW, Summerskill WH. Relations between pancreatic enzyme outputs and malabsorption in severe pancreatic insufficiency. $N$ Engl J Med 1973; 288: 813-5.

13 Konturek SJ, Tasley J, Obtulowicz W. Characteristics of inhibition of pancreatic secretion by glucagon. Digestion 1974; 10: 138-49.

14 Lin T-M, Evans DC, Chance RE, Spray GF. Bovine pancreatic peptide: action on gastric and pancreatic secretion in dogs. Am J Physiol 1977; 232: E311-5.

15 Bloom SR, Adrian TE, Greenberg GR, et al. Effects of pancreatic polypeptide infusion in man (abstract). Gastroenterology 1978; 74: 1012.
16 Malagelada J-R, Go VLW, Summerskill WH. Altered pancreatic and biliary function after vagotomy and pyloroplasty. Gastroenterology 1974; 66: 22-7.

17 Barrowman JA, Mayston PD. The trophic influence of cholecystokinin on the rat pancreas (abstract). $J$ Physiol (Lond) 1974; 238: 73P-5P.

18 Mainz DL, Black O, Webster PD. Hormonal control of pancreatic growth. J Clin Invest 1973; 52: 2300-4.

19 Grossman MI, Greengard H, Ivy AC. On the mechanism of the adaptation of pancreatic enzymes to dietary composition. Am J Physiol 1944; 141: 38-41.

20 Felber JP, Bandule-Dick J, der Kalbermatten N. Enteric control of the pancreas. In: Bloom SR, ed. Gut hormones. Edinburgh: Churchill Livingstone, 1978: 310-3.

21 Otte M, Stahlheber H, Forell MM, et al. Exokrine Pankreasfunktion bei chronischer Niereninsuffizienz. Klin Wochenschr 1975; 53: 67-72.

22 Bartos V, Melichar J, Erben J. The function of the exocrine pancreas in chronic renal disease. Digestion 1970; 3: 33-40.

23 Poll VM, Werner J, Huber W, Kempmann G, Willig F. Exokrine Pankreasfunktion bei chronischer Niereninsuffizienz. Z Gastroenterol 1979; 17: 177-86.

24 Gerhardt VW, Stein G, Bosseckert H, Graupner C, Noske A. Exkretorische Pankreasfunktion bei Niereninsuffizienz. Z Gesamte Inn Med 1974; 29: 895-9.

25 Wittich K-A, Schmidt H, Scheler F, Creutzfeldt W. Exokrine Pankreasfunktion bei chronischer Niereninsuffizienz. Verh Dtsch Ges Inn Med 1968; 74: 1072-4.

26 Baggenstoss AH. The pancreas in uremia: a histopathologic study. Am J. Pathol 1948; 24: 1033-17.

27 Avram MM. High prevalence of pancreatic disease in chronic renal failure. Nephron 1977; 18: 68-71. 